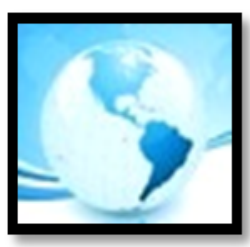

MALAYSIAN ONLINE JOURNAL OF

EDUCATIONAL MANAGEMENT

(MOJEM)

OCTOBER 2020, VOLUME 8, ISSUE 4, 79-97

E-ISSN NO: $2289-4489$

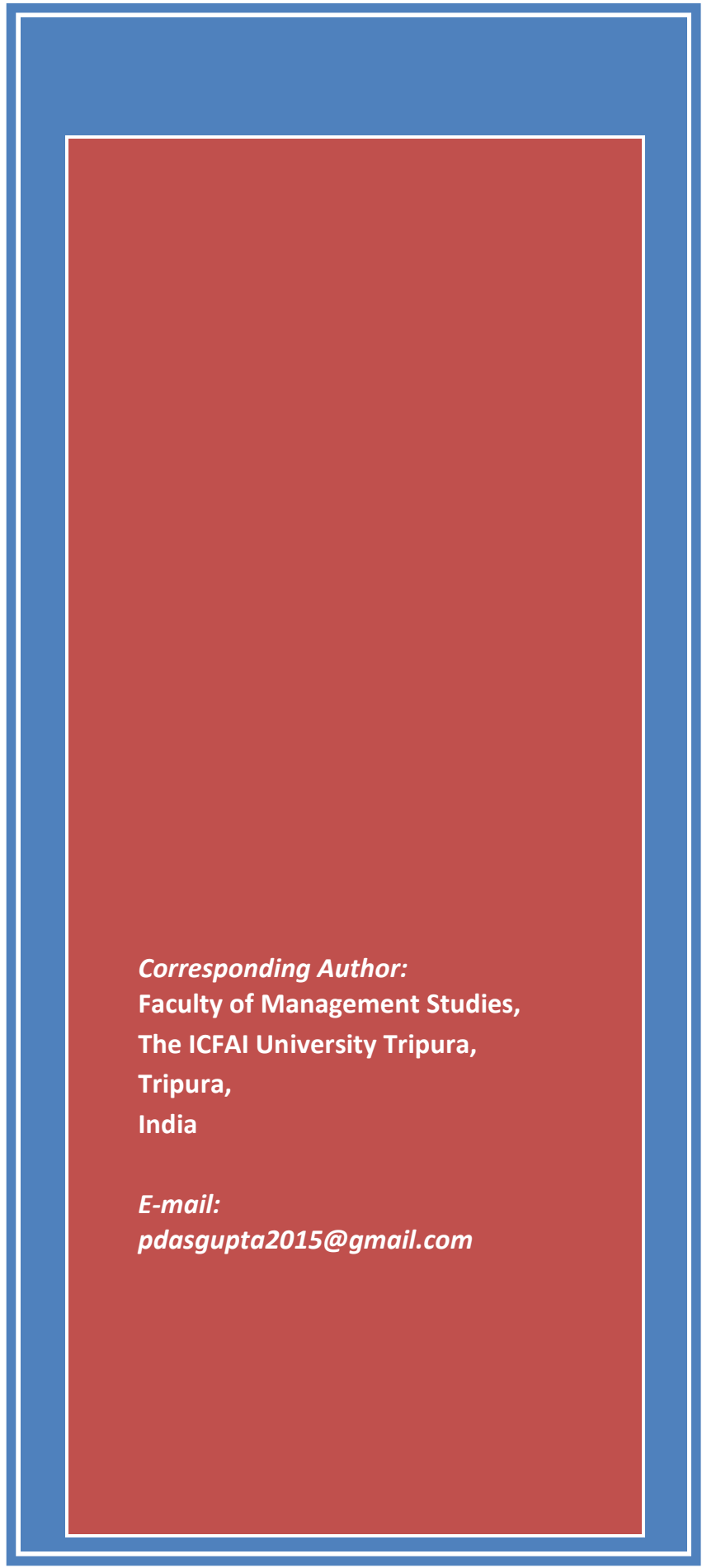

\section{A STUDY ON EMOTIONAL INTELLIGENCE AND UNIVERSITY CITIZENSHIP BEHAVIOR OF STUDENTS PURSUING MANAGEMENT EDUCATION IN THE UNIVERSITIES OF TRIPURA, INDIA \\ Prasanjit Dasgupta (PhD)}

\section{ABSTRACT}

Young men and women study management courses from Universities to take up responsible jobs in Corporate Sectors where they need to display high Emotional Intelligence (EI) and citizenship behaviour. Universities try to develop EI of its students pursuing management courses and citizenship behaviour by involving them in several activities. Some researchers have indicated that El of the employees relates positively to their organizational citizenship behaviour, hardly any study has explained the relationship between EI and University Citizenship Behaviour (UCB) of the students. This study has been undertaken to examine the relationship between EI and UCB, and its different dimensions. This study has also been made to explore the differences in emotional intelligence, its components, and that of UCB and its dimensions between Postgraduate (PG) and Undergraduate (UG) Management Students and female/male students. Sample of 217 full -time management courses from two Universities of Tripura, India, participated in the study, half of them were from UG and almost half were male. The scale designed by Schutte et al. (1998) on El and that of U-Thaiwat, Supparerkchaisakul, Mohan, and Fansler (2017) about UCB was used in the study; data were analysed using different parametric tools. The findings of the study show that the El of the students affects positively their UCB and its different dimensions. PG students scored higher in $\mathrm{El}$ and all its components, $\mathrm{UCB}$, and all its dimensions, university environment, and curriculum of management education may be attributed to these differences Female students ranked higher in Perception of Emotion component of El and all dimensions of UCB. This finding can be ascribed partially to the Indian value system where women are expected to empathize more about the need of the others than men. This study may be useful for University Authorities to devise a curriculum for their management education.

Keywords: Emotional Intelligence, Components of Emotional Intelligence, University Citizenship Behaviour, Dimensions of University Citizenship Behaviour 


\section{MALAYSIAN ONLINE JOURNAL OF EDUCATIONAL MANAGEMENT (MOJEM)}

\section{INTRODUCTION}

Management education is aimed at developing the leadership quality of the students, improving their decision-making skills, developing their problem-solving and team-building ability. The curriculum of management education trains the students to develop better human relations skills which can be possible only if the students develop an awareness of their emotions and that of the others, can regulate others' emotions in the needed situation and use emotion for planning, creative solution, and motivating their team members, customers, and other stakeholders in the industry. All these adaptive abilities have been considered as components of Emotional Intelligence (Salovey \&Mayer, 1990). These students are groomed to take up a future managerial role in industries where they need to get the job done with others and through others. Working with the team and motivating others to achieve the objective of the organization is the prime responsibility of modern managers. Studies have indicated that emotional intelligence can increase because of training (e.g., Mattingly \& Kraiger, 2018; Nelis, Quoidbach, Mikolajczak, \& Hansenne, 2009).

Emotional intelligence is going to be more prominent in the corporate world as stated in Harvard Business Review. Beck and Libert (February 2017) opined that artificial intelligence is going to play a dominant role in the future. It is going to replace a lot of technical and analytical assignments as machines will be best able to diagnose and bring in better business solutions than a professional analyst. They explained that it is the ability to create and develop the motivation of others, ability to lead others and delivery shall be the sought after qualities that will be largely desired from management graduates (Beck \& Libert, 2017)

Salovey and Mayer(1990) have defined Emotional Intelligence as "the subset of social intelligence that involves the ability to monitor one's own and others' feelings and emotions, to discriminate among them and to use this information to guide one's thinking and actions"(p189)

Several researchers have found the influence of emotional intelligence on the positive behaviour of human beings such as better interpersonal relationships (Schutte et al., 2001); higher performance of executives (Mishra \& Mahapatra, 2010), cooperative behaviour (Schlegel, Mehu, van Peer, \& Scherer, 2017). Meta-analyses which combine results of many indices indicate that in the workplace more intelligent employees tend to perform well in high emotional labour work (Joseph \& Newman, 2010) display superior leadership (Harms \&Crede, 2010) and show better work performance (O' Boyle, Humphrey, Pollack, Hawver, \& Story, 2011). Emotional Intelligence is considered as a quality for successful adaptation in different events of life (Jain, 2012), more constructive conflict management (Schlaerth, Ensari, \& Christian, 2013), better academic adjustment of students, and life satisfaction (Cazen \&Nastasa, 2014). Students high in emotional intelligence has also been found to be less prone to stress and burnout (Cazen \&Nastasa, 2014).

University Citizenship Behaviour (UCB) has been derived from Organizational Citizenship Behaviour (OCB) which means extra-role discretionary behaviour one performs in the organization without expectation of any favour or reward. OCB significantly relates to job performance (Basu, Pradhan, \& Tewari, 2017; Ismail, Iqbal, \& Adeel, 2018), job satisfaction, life satisfaction, and negatively related to turnover intent and burnout of employees (Lambert, 2010), job satisfaction and organizational commitment (Dargahi \&Morshedi, 2017).

Students are not employees but have several scopes of exercising discretionary behaviour without expectation of score or reward. Their discretionary behaviour may include helping a fellow student in studies, circulating study materials that may be useful to all the classmates, helping university management in enhancing sensibility of keeping the campus clean, helping the teacher in fixing up a projector or other accessories in the class, raising voice against ragging, against intoxication, advocating the University before people and helping students known to them for Admission in the University, etc. These have far-reaching implications for Management students as they are trained to be future corporate citizens where they need to exhibit OCB frequently, application of UCB will help them in the future as these would inculcate practice in them to contribute to the organization without expectation 


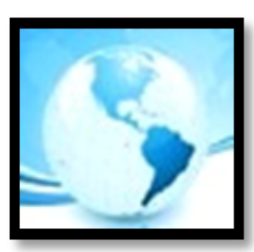

\section{MALAYSIAN ONLINE JOURNAL OF EDUCATIONAL MANAGEMENT (MOJEM)}

of favour or reward. The contradictory situation as has been elaborated by U-Thaiwat et al. (2017) is that lack of desirable behaviour if developed by university students would lead to social problems as students being future of the organizations shall bring those behaviours learned in universities. U-Thaiwat et al. (2017) have rephrased to some extent meaning of five dimensions of OCB suiting to the context of University Students, added two more, and described seven dimensions of University Citizenship Behaviour as altruism, civic virtue, conscientiousness, courtesy, sportsmanship, enthusiasm, and interpersonal relations.

Several studies have been made to explore the relationship between OCB and Emotional Intelligence. A positive relationship between OCB and Emotional Intelligence has been found in the study of Jain (2009), Yaghoubi, Mashinchi, and Hadi (2011), Yunus (2012), Vandewaa and Turnipseed (2012), Antony (2013), Chehrazi and Shakib (2014), and Tofighi, Tirgari, Fooladvandi, Rasouli, and Jalali (2015). Impact of Emotional Intelligence on different dimensions of OCB has been found in the study of Vandewaa, Turnipseed, and Cain (2016) who observed that the effort of managers to enhance the emotional intelligence of nurses positively affects their conscientiousness and altruistic behaviour. Candigarh and Vasisht (2017) in their study emphasized that a strong relationship between Emotional Intelligence and OCB of employees is key for the overall success of an organization. Some studies like Chin, Anantharaman, and Tong (2011) demonstrated that high emotional intelligence does not always have bearing on high OCB and they opined that it is based on the type of industry whether it is capital intensive and labour-intensive.

Universities undertake several exercises like regular soft-skill courses, team-building processes, case analysis, management games, etc. for management students to enhance their emotional intelligence. At the same time, Citizenship Behaviour is augmented by encouraging students to be cooperative and engaging in community and student welfare schemes. Relationship between Emotional Intelligence and UCB needs to be examined regarding Management Students as they are being trained in this direction in their curriculum and both shall be essential for their future assignments. Hardly any study has examined the relationship between Emotional Intelligence and University Citizenship Behaviour of Management Students whose curriculum and evaluation process are different to a good extent from those pursuing studies in other disciplines. Considering the curriculum management students pursue in universities and it has been proved by some research that training impacts emotional intelligence (e.g., Mattingly \& Kraiger, 2018; Nelis et al., 2009) and on OCB (e.g., Ahmad, 2011; Nasurdin, Ahmad, \& Tan, 2014) and UCB is a derivative of OCB, it is expected that those completing their Post-Graduate (PG) Program shall display higher University Citizenship Behaviour and better Emotional Intelligence than those in UnderGraduate (UG) Management Students. Mishra and Mahapatra (2010) did not find any difference between men and women executives regarding emotional intelligence whereas Pooja and Pranab (2016) in their longitudinal study on Indian Service Sector employees observed women as high in emotional intelligence than men. Ariani (2013) found significant differences in OCB between male and female employees. Ng, Lam, and Feldman (2016) did not find any differences between males and females about their OCB.

Research Questions

1. Is the Emotional Intelligence of Management Students related to their University Citizenship Behaviour and its different dimensions?

2. Are Emotional Intelligence and its components, UCB and its dimensions is generally high in Post Graduate Management Students than those in UG level?

3. Do Emotional Intelligence and its components, UCB, and its dimension vary between male and female Management Students?

The study has been made among Management Students of the Universities in Tripura, a province located in the North-Eastern part of India. 


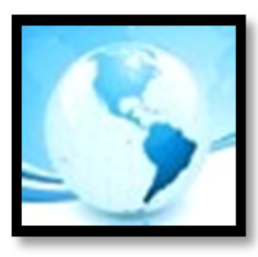

MALAYSIAN ONLINE JOURNAL OF

EDUCATIONAL MANAGEMENT

(MOJEM)

\section{LITERATURE REVIEW}

Ueda and Yoshimura (2010) described university citizenship behaviour as the discretionary behaviour of students for the betterment of the university without expectation of higher scores or benefits for doing so. U-Thaiwat et al (2017) defined UCB as behaviours that students willingly perform to benefit their university both directly and indirectly without negatively affecting others. Neither extra scores nor the threat of punishment is explicitly involved (U-Thaiwat et al., 2017).

Researchers like Ehtiyar, Alan and Omiiris (2010) and Popescu and Desconu (2013) in their study on OCB of High School and University Students described five dimensions of OCB changing the construct suiting to the students' activities. Their five dimensions of OCB of students are altruism, civic virtue, conscientiousness, courtesy, and sportsmanship. U-Thaiwat et al. (2017) analysing Ehtiyar et al.(2010) and Popescu and Desconu (2013) and after conducting a qualitative and quantitative study on a sample of American and Thai Students suggest following seven dimensions of University Citizenship Behaviour:

Altruism includes help to friends and peers in an academic set up and also helps teachers to facilitate the learning process. This also covers students' help to teachers in non-academic settings. Civic Virtue indicates a behaviour that students show when they act as part of the University and positively respond to the guidelines of University. It reflects students' involvement in a positive manner in the functions of the University. The term Conscientiousness includes the behaviour of students where they go beyond the minimum requirement to take care of the University's betterment. Here consciousness also covers the behaviour that students demonstrate outside the classroom such as community development, maintenance of ecology, etc. Courtesy means the sense displayed by students to see how their behaviours affect their surroundings and neighbours. Here students remain vigilant to see that their behaviour doesn't offend or cause annoyance to others whether in the classroom or outside. Sportsmanship is the accommodative behaviour that students show when they face inconvenience. This includes patience and tolerance at the time of crisis or unwanted situation. Students are expected to look for solving the problem instead of blaming others for the situation. U-Thaiwat et al. (2017) adding the new dimension 'enthusiasm' described it as students' interest in academic work. They argued that students take interest in academic work to excel. This helps them in better learning and benefits the University and later on society. The seventh dimension of building interpersonal skills may help the students to exchange the learning process. This will also make them more acceptable to members of the society in the future, has been stated by U-Thaiwat et al. (2017).

Emotional Intelligence has been described as a valid measure of how emotion is used and accessed and is measured by peoples' self-perception of their emotional abilities. It is stated as an emotional quotient that one possesses to be able enough to take decisions and control factors that affect one's emotion. Salovey and Mayer (1990), supported by Petrides, Hudry, Michalaria, Swami, and Sevdalis (2011) and Pekaar,Bakker, Born, and van der Linden (2018) described emotional intelligence as competencies to effectively deal with emotions to handle social and emotional behaviour.

Different models have described the construct of emotional intelligence. Salovey and Mayer (1990) stated that it consists of the following three categories of adaptive abilities (Schutte et al., 1998): (1) Appraisal and Expression of Emotion in self and Appraisal of Emotion of the others; (2) Regulation of the emotion of self and regulation of emotion of the others; and (3) Utilizing emotion for flexible planning, creative thinking redirected attention and motivation.

Goleman (1995) described the main areas of emotional intelligence as: (1) Knowing one's emotion; (2) Managing one's emotion; (3) Motivating one-self; (4) Recognizing emotions in others; and (5) Handling relationships 
Mayer and Salovey (1997) revised their earlier model and said emotional intelligence consists of four abilities: (1) Perception, appraisal, and expression of emotion; (2) Emotional facilitation of thinking; (3) Understanding and analysing emotions, employing emotional knowledge; and (4) Reflective regulation of emotions to promote emotional and intellectual growth.

Bar-On (1997) proposed a model of El wherein El has been described as a set of non-cognitive skills and competencies that influence a person's ability to succeed in coping with the demand of the environment.

Schutte et al. (1998) described emotional intelligence as a one-dimensional construct, Le Pine et al. (2002) supported by Hoffman et al. in their meta-analysis described OCB as a latent construct wherein its dimensions overlap each other. Taking a cue from OCB research as UCB is a derivative of OCB, UCB may be considered as a latent construct. University Citizenship Behaviour involves helping relationships with other students, teachers, and social relationships with community and surrounding, discipline, and abidance to university regulations. All these require the skill of perceiving surroundings, understanding the emotion of self and others, and utilizing emotion for executing the task for the common good of the university, students, and community.

It is hypothesized:

HI: Emotional Intelligence of the Management Students significantly relate to University Citizenship Behaviour and its dimensions

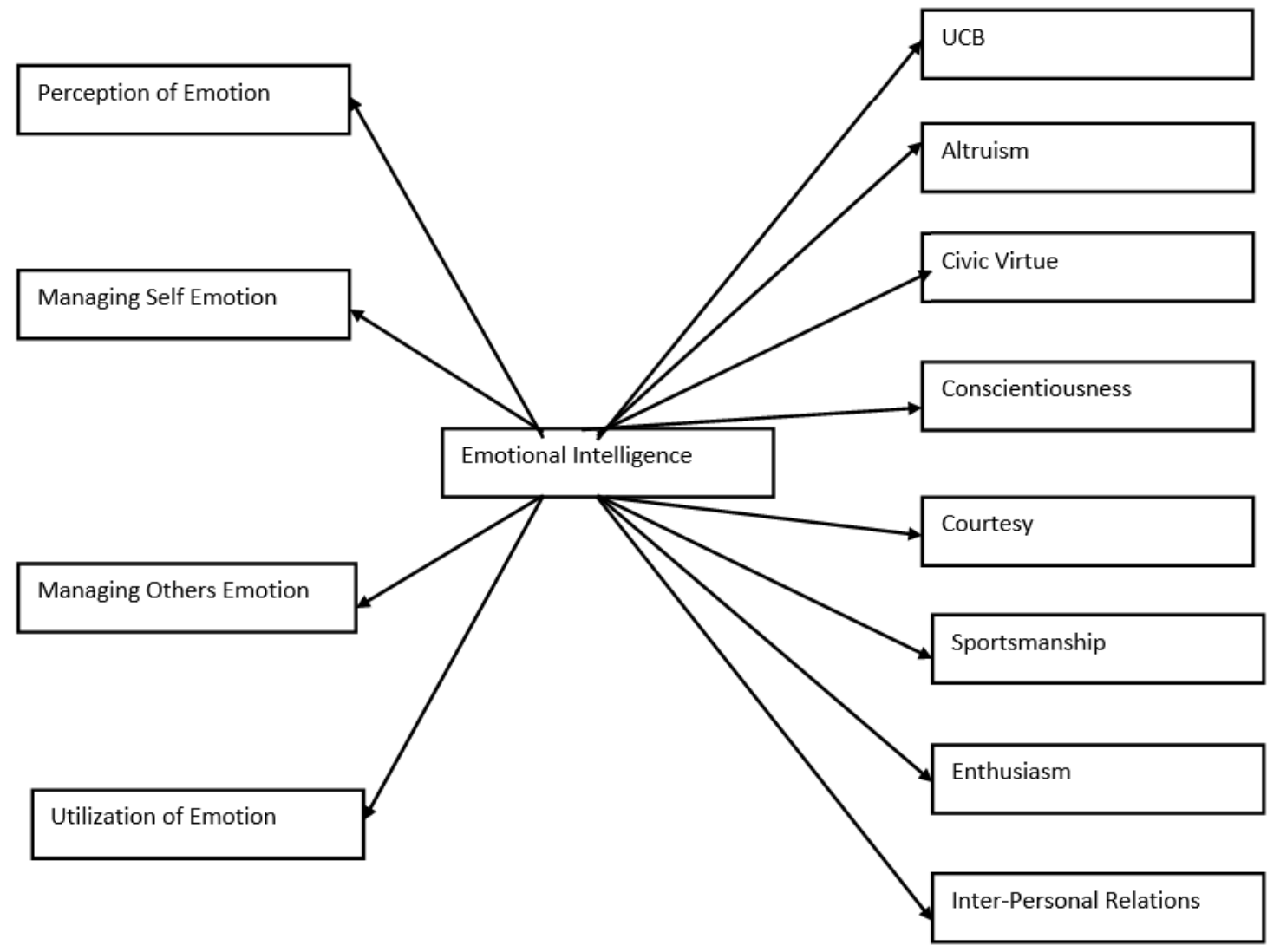

Figure I. Hypothesized Relationship Model 


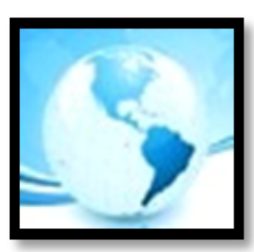

\section{MALAYSIAN ONLINE JOURNAL OF EDUCATIONAL MANAGEMENT (MOJEM)}

Students pursuing Undergraduate Management Programs of University are direct entrants from high school where hardly any systematic device is followed to enhance Emotional Intelligence and citizenship behaviour of the Students. In high school, education is mostly concerned with imbibing the knowledge of subjects like language, history, basic science or commerce, and economics. The curriculum of Management Education through various techniques like relating theory to practice and simulation techniques, projects of community development and team building techniques brings in a sense of realization on self about awareness of their emotion and knowledge of others emotion and thereby develop a willingness to walk an extra mile for the benefit of surrounding and fellow students. They also develop an appreciation of others' emotions and the ability to use emotion for motivating others, use emotion for solving the problem of self and others for a greater cause, helping others and serve the society. Nelis et al (2009) in a six-month-long study between the experimental group and control group demonstrated that emotional intelligence increased in the experimental group than that of the control group due to training and learning. Hodzic, Scharfen, Ripoll, Holling, and Zenashi (2017) in their meta-analysis of 24 studies involving 28 samples opined that training interventions enhance the Emotional Intelligence of the candidates. Mattingly and Kraiger (2018) based on their meta-analysis of 56 published and unpublished studies observed that training causes a positive effect on emotional intelligence irrespective of design. It is expected because of training students pursuing Post Graduate Management Courses score high in terms of the components of emotional intelligence and dimensions of UCB than that of the Under-Graduate Students.

It is hypothesized:

HII: Components of Emotional Intelligence and Dimensions of UCB is higher among Post Graduate management students than Under-Graduate Management Students

Gender is an important influence on the OCB of employees. Lovell et al. (1999) observed that women employees scored higher on OCB than men. Farrell and Finkelstein (2007) found women in general display higher OCB, only altruism dimension was higher for men. Even in far-east Wanxian and Weiwu (2007) opined that gender to some extent is an important antecedent for OCB. UCB is a derivative of OCB and all the dimensions of OCB have been included in UCB with certain modifications along with two more dimensions

Several studies have found that women understand better emotion of others than men whereas some has indicated that gender does not influence emotional intelligence. Wojciechowski, Stolarski, and Matthews(2014) based on their experiment on Face Decoding Test (FDT) observed that Emotional Intelligence was more strongly related to facial decoding performance of women than men Pooja and Pranab (2016) in their longitudinal study on Indian Service Sector employees observed that women score higher than men in emotional intelligence. Michael, Anthony and Amy (2015) on a self-report measure of emotional intelligence found that women scored higher than males. Fischer, Kret, and Broekens (2018) on a large community sample of 5000 participants did not find any significant difference in emotional sensitivity between male and female participants regarding target emotion but about non-target emotion, males scored higher than women. It is debatable to say that women score high regarding emotional intelligence or men it can be safely assumed that there is a significant difference between men and women.

It is hypothesized:

HIII: University Citizenship Behaviour and its dimensions, Emotional Intelligence and its components vary between male and female management students

\section{METHODS}

In the two Universities of Tripura1000 students are currently studying management in the undergraduate and post-graduate levels. For the study, 250 questionnaires were circulated among the Management Students of the Universities of Tripura. Cluster Sampling Method was taken i.e. Questionnaires were equally distributed among 


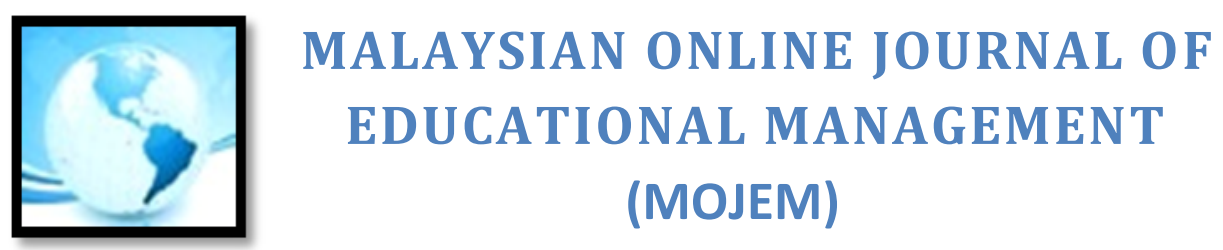

Undergraduate and Postgraduate students and in the same manner among male and female students, the effort has been made to include at least one student out of four in the respective course and gender.

The scale designed by U-Thaiwat et al. (2017) was used for exploring University Citizenship Behaviour in the study as it was found reliable in its study in the USA and Thailand. Permission to use the Scale was duly granted by the authors. It is a 5-Point rating scale with 35 items ranging from 1= Not True at all to 5= Extremely True. Out of 35, 4 items are reverse worded, seven dimensions of UCB (U-Thaiwat et al., 2017) in the scale are altruism (Item 1 to 6), civic virtue (Item 7 to 11), conscientiousness (Item 12 to 18), courtesy (Item 19 to 22), sportsmanship (Item 23 to 26), enthusiasm (Item 27 to 30), interpersonal relations (Item 31 to 35).

To measure the Emotional Intelligence, the scale of Schutte et al. (1998) has been used. It is a 5- Point Scale prepared based on the model of Salovey and Mayer (1990). Schutte et al. (1998) viewed that the original construct of Salovey and Mayer (1990) is leading to the better conceptualization of various dimensions of an individual's emotional development and most of the dimensions of other models can be integrated into this model (Schutte et al., 1998). Out of the total 33 items, 13 items were from appraisal and emotion expression of the model; 10 from those of emotion regulation and 10 were from the utilization of the emotion category of the model (Schutte et al., 1998) and 3 of them were reverse coded. It is a 5-Point rating scale ranging from 1= Strongly Disagree to 5= Strongly Agree (Schutte et al., 1998; Schutte, Malouff, \& Bhullar, 2009), all the items have been summed up and scores ranged from 33 to 165 (Schutte et al., 2009). Authors permitted free use of the scale for research and hence no formal permission was required. This scale was originally used in assessing the emotional intelligence of therapists, therapy clients, and prisoners. Ciarrochi, Chan, and Bajgar (2001) identified four factors in the Scale of Schutte et al.(1998) as the perception of emotions (Item 5,9,15,18,19,22, 25,29,32,33) managing emotions in the self (Item 2,3,10,12,14,21,23,28,31) , social skills or managing others' emotions (Item 1,4,11,13, 16,24, 26,30), and utilizing emotions (Items 6,7,8, 17,20,27) (Ciarrochi et al., 2001).

To ensure the confidentiality the Questionnaires were unnamed, and each respondent was clearly explained about the purpose of the study and were assured about the maintenance of confidentiality. 217 respondents filled up the Questionnaires, out of 35 items 4 carried negative value. The score of the respondents was reversed regarding those items, SPSS .20 used for the analysis. Out of 217 respondents, 108 were Under-Graduate and 109 were female students, age group of the students was 21-24 years with average age 21.3 years of UG Students and 23.6 years of PG Students.

To find out lost data descriptively the data was analysed and no missing data was detected in EI and UCB and their dimensions, it has been found in all of them 217 was the figure of respondents.

To check the normality of the data Skewness and Kurtosis Coefficients of EI, UCB, and their dimensions were examined. Table I shows the detail: 
Table I

Normality Analysis

\begin{tabular}{llllll}
\hline & $\mathrm{N}$ & $\begin{array}{l}\text { Skewness } \\
\text { Statistics }\end{array}$ & Std. Error & Statistics & Std. Error \\
\hline Emotional Intelligence & 217 & -.121 & .165 & -.842 & .329 \\
Perception & 217 & -.135 & .165 & -.843 & .329 \\
Own Emotion & 217 & -.353 & .165 & -.111 & .329 \\
Others' Emotion & 217 & -.270 & .165 & -.773 & .329 \\
Utilization of Emotion & 217 & -.358 & .165 & -.572 & .329 \\
UCB & 217 & .607 & .165 & .763 & .329 \\
Altruism & 217 & 1.466 & .165 & 5.825 & .329 \\
Civic Virtue & 217 & .293 & .165 & -.571 & .329 \\
Conscientiousness & 217 & .119 & .165 & -.047 & .329 \\
Courtesy & 217 & .418 & .165 & .693 & .329 \\
Sportsmanship & 217 & .191 & .165 & .115 & .329 \\
Enthusiasm & 217 & .724 & .654 & 1.315 & .329 \\
Interpersonal Relation & 217 & .836 & .165 & & .329 \\
\hline
\end{tabular}

Skewness Coefficients of all Variables excepting that of Altruism is within +/- 1 which indicates that the variables may not be skewed (Uyanik \&Guler, 2013), similarly Kurtosis Coefficients of all variables excepting that of altruism and interpersonal relations are within the range of $+/-1$. All these indicate that the data is moderately symmetrical.

Reliability Test of the Scale of U-Thaiwat et al. (2017) and that of Schutte et al. (1998) on the Sample showed Cronbach's Alpha at .883, and .919 respectively. Correlations between different components and that of Emotional Intelligence and that of UCB with its different dimensions are highly significant which indicates their reliability. Details are given in Table 2:

Table 2

Correlation Analysis of EI \& Components; UCB \& Dimensions

\begin{tabular}{|c|c|c|c|c|c|c|c|c|c|}
\hline EI & $\begin{array}{l}\text { Perception } \\
\text { Emotion }\end{array}$ & of & $\begin{array}{l}\text { Managing } \\
\text { Emotion }\end{array}$ & Own & Managir & hers' Emotior & \multicolumn{3}{|c|}{$\begin{array}{l}\text { Utilization } \\
\text { Emotion }\end{array}$} \\
\hline R 1 & $.837^{* *}$ & & $.852 * *$ & & $.899 * *$ & & & $/ 839 * *$ & \\
\hline Sig. & .000 & & .000 & & .000 & & & .000 & \\
\hline UCB & Altruism & Civic Virtue & $\begin{array}{l}\text { Conscientiousnes } \\
\mathrm{s}\end{array}$ & & urtesy & $\begin{array}{l}\text { Sportsma } \\
\text { nship }\end{array}$ & & thusias & IPR \\
\hline R 1 & $.961 * *$ & $.962 * *$ & $.965 * *$ & & $68 * *$ & $/ 966 * *$ & & $67 * *$ & $.963 * *$ \\
\hline Sig. & .000 & .000 & .000 & .0 & 00 & .000 & .00 & 00 & .000 \\
\hline
\end{tabular}

**Correlation significant at .01 levels (two tailed)

*Correlation significant at .05 levels (two tailed)

\section{RESULTS}

To find the relationship of Emotional Intelligence with UCB and its different dimensions Pearson's Correlation Analysis was undertaken, Table I shows the analysis: 


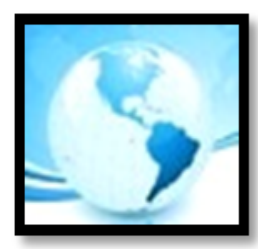

MALAYSIAN ONLINE JOURNAL OF

EDUCATIONAL MANAGEMENT

(MOJEM)

Table 3

Correlation Analysis of El and UCB, its Dimensions

\begin{tabular}{llllllllll}
\hline & EI & UCB & Altruism & $\begin{array}{l}\text { Civic } \\
\text { Virtue }\end{array}$ & $\begin{array}{l}\text { Conscienti } \\
\text { ousness }\end{array}$ & Courtesy & $\begin{array}{l}\text { Sportsman } \\
\text { ship }\end{array}$ & $\begin{array}{l}\text { Enthusia } \\
\text { sm }\end{array}$ & IPR \\
\hline$r$ & 1 & $.471^{* *}$ & $.458^{* *}$ & $.461^{* *}$ & $.432^{* *}$ & $.450^{* *}$ & $.457^{* *}$ & $.472^{* *}$ & $.479^{* *}$ \\
Sig. & .000 & .000 & .004 & .000 & .000 & .000 & .000 & .000 \\
\hline
\end{tabular}

**Correlation significant at .01 levels (two tailed)

*Correlation significant at .05 levels (two tailed)

Table 3 indicates Emotional Intelligence significantly relates to UCB and all its dimensions.

Regression Analysis was undertaken to explore the variance caused by Emotional Intelligence on UCB and all its dimensions. Table 4 displays the analysis:

Table 4

Regression Analysis

\begin{tabular}{lllllll}
\hline IV & DV & Adj. r. Sq. & t-Value & Beta & Sig. & VIF \\
\hline EI & UCB & .218 & 7.824 & .471 & .000 & 1.000 \\
EI & Altruism & .206 & 7.547 & .458 & .000 & 1.000 \\
EI & Civic Virtue & .209 & 7.618 & .461 & .000 & 1.000 \\
EI & Conscientiousness & .183 & 7.017 & .432 & .000 & 1.000 \\
EI & Courtesy & .199 & 7.392 & .450 & .000 & 1.000 \\
EI & Sportsmanship & .205 & 7.540 & .457 & .000 & 1.000 \\
EI & Enthusiasm & .219 & 7.841 & .472 & .000 & 1.000 \\
EI & Inter-Personal & .226 & 7.999 & .479 & .000 & 1.000 \\
& Relationship & & & & &
\end{tabular}

Table IV indicates the strength of the relationship between EI and UCB (Beta .471, sig.000); EI and Altruism (Beta.458, sig. 000); El and Conscientiousness (Beta.461, sig. 000), El and Courtesy (Beta .450, sig. 000), El and Sportsmanship (Beta. 457, sig.000), El and Enthusiasm (Beta .472, sig. 000); EI and IPR (Beta .479. sig.000). Adj. $r$ sq. with UCB, Altruism, Civic Virtue Conscientiousness, Courtesy, Sportsmanship, Enthusiasm and IPR (.218, .206, $.209, .183, .199,205, .219$ and .226$)$ indicates the Goodness of the model, with t- Value $(7.824,7.547,7.618,7.017$, $7.392,7.540,7.841$ and 7.999) shows rejection of null hypotheses. VIF score 1 show there is no Multicollinearity effect.

This analysis proved Hypothesis I

Observed relationship has been given in Figure 2. 


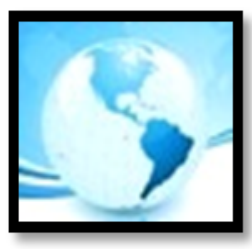

MALAYSIAN ONLINE JOURNAL OF

EDUCATIONAL MANAGEMENT

(MOJEM)

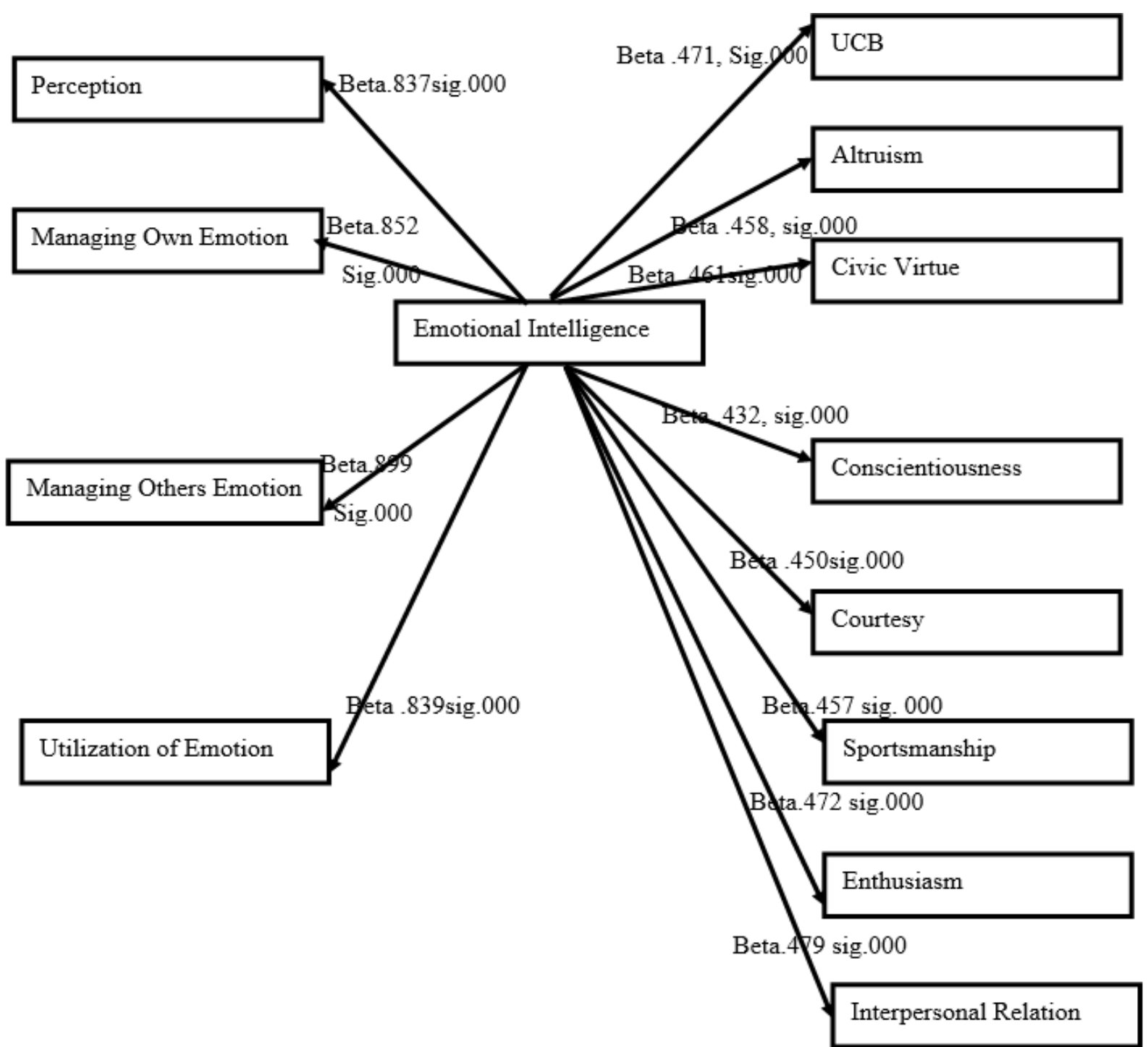

Figure 2. Relationship between Emotional Intelligence with UCB and its Dimensions

To explore the differences of Emotional Intelligence, its components, University Citizenship Behaviour, its dimensions between the Undergraduate and Postgraduate students, Independent Sample T Test and ANOVA was conducted. Its analysis has been given in Table 5 below: 


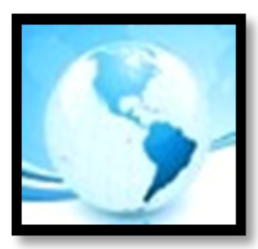

MALAYSIAN ONLINE JOURNAL OF

EDUCATIONAL MANAGEMENT

(MOJEM)

Table 5

Independent Sample T Test \& ANOVA of UG and PG Students

\begin{tabular}{|c|c|c|c|c|c|c|}
\hline \multirow[t]{2}{*}{ Item } & \multicolumn{2}{|c|}{ Mean } & \multicolumn{2}{|c|}{ S.D. } & \multirow[t]{2}{*}{$t$-Value } & \multirow[t]{2}{*}{ Sig. } \\
\hline & PG & UG & PG & UG & & \\
\hline Perception & 36.17 & 30.43 & 5.37 & 4.14 & 8.831 & $.000 * *$ \\
\hline Managing Own Emotion & 31.22 & 29.4 & 5.70 & 4.99 & 2.487 & $.014^{*}$ \\
\hline Managing Others' Emotion & 27.55 & 25.10 & 6.48 & 5.05 & 3.116 & $.002 * *$ \\
\hline Utilization of Emotion & 22.86 & 19.64 & 4.69 & 3.53 & 5.702 & $.000 * *$ \\
\hline Emotional Intelligence & 117.82 & 104.58 & 20.02 & 13.7 & 5.694 & $.000 * *$ \\
\hline Altruism & 13.28 & 8.97 & 2.49 & 1.18 & 16.320 & $.000 * *$ \\
\hline Civic Virtue & 11.57 & 7.45 & 1.59 & 1.21 & 21.420 & $.000 * *$ \\
\hline Conscientiousness & 17.94 & 13.19 & 1.80 & 1.72 & 19.846 & $.000 * *$ \\
\hline Courtesy & 9.80 & 6.50 & 1.57 & 1.26 & 17.026 & $.000 * *$ \\
\hline Sportsmanship & 11.27 & 7.94 & 1.39 & 1.24 & 18.585 & $.000 * *$ \\
\hline Enthusiasm & 9.30 & 6.17 & 1.59 & .94 & 17.647 & $.000 * *$ \\
\hline Inter-Personal & 13.17 & 9.59 & 2.07 & 1.24 & 15.416 & $.000 * *$ \\
\hline Relationship & & & & & & \\
\hline Overall UCB & 83.97 & 62.3 & 11.09 & 7.55 & 16.834 & $.000 * *$ \\
\hline
\end{tabular}

${ }^{*} p<.05 ;{ }^{* *} p<.01$

Independent Sample t-Test, ANOVA, and Canonical Discriminant Analysis show PG Students scored higher Mean than UG Students regarding El and its Components, UCB and its dimensions. Perception (with t 8.831, sig. 000 and Canonical Correlation .524); Managing Own Emotion (with t 2.487, sig.014 and Canonical Correlation .183); Managing Other's Emotion (with t 3.116, sig.002 and Canonical Correlation. 214) Utilization of Emotion (with $t$ 5.702, sig. 000 and Canonical Correlation .366) and Emotional Intelligence (t 5.694, sig. 000 and Canonical Correlation 371) Altruism dimension of UCB (with t 16.320, sig. 000 and Canonical correlation .746); Civic Virtue (with t 21.420, sig.000 and Canonical correlation .829); Conscientiousness (with t 19.846, sig.000 and Canonical Correlation .807); Courtesy (with t 17.026, sig.000 and Canonical Correlation .762); Sportsmanship (with t 18.585, sig.000 and Canonical Correlation .785); Enthusiasm (with t 17.647, sig.000 and Canonical Correlation .768); IPR (with t 15.416, sig. 000 and Canonical Correlation .728) and UCB (with t 16.834, sig. 000 and Canonical Correlation .757). All these results indicate significant differences between the PG and UG Students of the Sample.

Hypothesis II is conclusive.

To examine whether gender impacts components of emotional intelligence and UCB and its dimensions Independent Sample T-Test and ANOVA was conducted; details are as given in Table 6. 


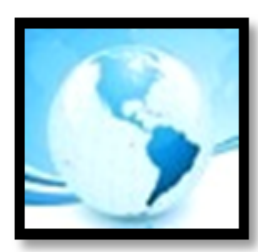

MALAYSIAN ONLINE JOURNAL OF

EDUCATIONAL MANAGEMENT

(MOJEM)

Table 6

Independent Sample T-Test and ANOVA of Female and Male Students

\begin{tabular}{|c|c|c|c|c|c|c|}
\hline \multirow[t]{2}{*}{ Item } & \multicolumn{2}{|c|}{ Mean } & \multicolumn{2}{|c|}{ S.D. } & \multirow[t]{2}{*}{ t- Value } & \multirow[t]{2}{*}{ Sig. } \\
\hline & Female & Male & Female & Male & & \\
\hline Perception & 34 & 32.44 & 5.86 & 5.07 & 2.11 & $.035^{*}$ \\
\hline $\begin{array}{l}\text { Managing Own } \\
\text { Emotion }\end{array}$ & 37.86 & 37.46 & 9.13 & 7.54 & .351 & .726 \\
\hline $\begin{array}{l}\text { Managing Others' } \\
\text { Emotion }\end{array}$ & 25.97 & 26.65 & 6.17 & 5.64 & -.853 & .395 \\
\hline $\begin{array}{l}\text { Utilization of } \\
\text { Emotion }\end{array}$ & 21.56 & 20.78 & 4.61 & 4.29 & 1.294 & .197 \\
\hline $\begin{array}{l}\text { Emotional } \\
\text { Intelligence }\end{array}$ & 111.42 & 110.30 & 21.09 & 15.37 & .050 & .960 \\
\hline UCB & 79.83 & 66.47 & 12.82 & 12.77 & 7.691 & $.000 * *$ \\
\hline Altruism & 12.5 & 9.8 & 2.83 & 2.3 & 7.81 & $.000 * *$ \\
\hline Civic Virtue & 10.78 & 8.25 & 2.01 & 2.3 & 8.62 & $.000 * *$ \\
\hline Conscientiousness & 17.11 & 14.02 & 2.27 & 2.76 & 8.99 & $.000 * *$ \\
\hline Courtesy & 9.21 & 7.09 & 1.80 & 2.01 & 8.16 & $.000 * *$ \\
\hline Sportsmanship & 10.7 & 8.5 & 1.68 & 1.94 & 8.90 & $.000 * *$ \\
\hline Enthusiasm & 8.73 & 6.74 & 1.64 & 1.72 & 8.21 & $.000 * *$ \\
\hline $\begin{array}{l}\text { Inter- Personal } \\
\text { Relationship }\end{array}$ & 12.55 & 10.21 & 2.26 & 2.11 & 7.89 & $.000 * *$ \\
\hline
\end{tabular}

$* p<.05 ; * * p<.01$

Independent t-Test and ANOVA indicate a significant difference between UCB and its dimensions as well as the Perception component of the Emotional Intelligence of Female and Male Students; the mean of all of them of the female is higher. UCB (t 7.691, sig.000, canonical correlation .485); Altruism (t 7.81, sig 000, canonical correlation .451); Civic Virtue (t 8.62, sig. 000, canonical correlation.489); Conscientiousness (t 8.99, sig.000, canonical correlation .508 ); Courtesy (t 8.16, sig.000, canonical correlation .470); Sportsmanship (t 8.9, sig.000, canonical correlation .502 ); Enthusiasm (t 8.21, sig.000, canonical correlation .470), IPR (t 7.89, sig.000, canonical correlation .459) and Perception of Emotion (t 2.11, sig. 035, canonical correlation .141). These results indicate that UCB, all its dimensions, and Perception of Emotion component of El is higher in female than male students. No significant difference found regarding Emotional Intelligence and its components of Managing Self Emotion, Managing others Emotion and Utilization of Emotion between female and male students.

Hypothesis III is partially proved

\section{DISCUSSION}

Emotional Intelligence is the ability to comprehend and regulate self and other's emotions as well as utilize it for furthering the motivation of others, solving problems as well as undertaking creative tasks is considered essential for management professionals. Studies have proved that emotional intelligence can be improved by training. University Citizenship Behaviour directed at discretionary extra-role behaviour of university students aimed at benefits of the university and its surrounding is essential particularly for management students who are the future corporate citizens where they are supposed to exercise extra-role behaviour for benefit of the organization frequently. Hence, many modern Universities have designed a curriculum for the development of emotional intelligence of management students by introducing several exercises like T-group training, simulation exercises aimed at solving real industry like situation, soft skill teaching classes, etc. Universities also involve management 


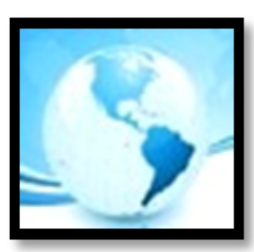

\section{MALAYSIAN ONLINE JOURNAL OF EDUCATIONAL MANAGEMENT (MOJEM)}

students in the different community development processes; encourage them to practice extra-role behaviour like including them in the admission of new students, their placement process, industry-academia interface, etc.

The study has been conducted to find the relationship between emotional intelligence with university citizenship behaviour and its different dimensions. It has been found that Emotional Intelligence significantly relates to University Citizenship Behaviour as well as to its entire dimension. Researchers like Naghdi and Shatalebi (2013) demonstrated that Emotional intelligence significantly relates to the entire dimensions of OCB. This result is also in congruence with that of (Turnipseed \&Vandewaa, 2012; Vandewaa \& Turnipseed, 2012; Vandewaa et al., 2016) who found that emotional intelligence exerts a significant positive influence on altruism and conscientiousness dimension of organizational citizenship behaviour. A meta-analysis of Miao, Humphrey, and Qian (2017) too observed a significant relationship between emotional intelligence and OCB.

Studies have indicated that the emotional intelligence of students positively affects their academic achievement (Costa \& Faria, 2015; MacCann, Fogarty, Zeidner, \& Roberts, 2011). Since students with high emotional intelligence are usually good in studies, they are often asked for help by classmates and are also sought after by the Faculty at time. This has been referred to as altruism by U-Thaiwat et al. (2017). Emotionally intelligent people are participative to the happening of the surrounding; similarly, these students are also interested in the neighbouring activities apart from going to the classes. This dimension is civic virtue and is significantly related to emotional intelligence. The conscientiousness behaviour of the students indicates their desire to walk the extra mile for the betterment of the university. People with higher emotional intelligence prefer to be liked by the system and remain in the good book of the establishment. They consider themselves as part of the organization and treat themselves as a brand ambassador so that people identify them as a product of a good university. People with high emotional intelligence try to perceive and manage other emotions. The courtesy dimension of UCB indicates people's concern to find how their action affects people adjacent. Emotional Intelligence is significant to this dimension of UCB. Perception of the situation and utilizing it in the right direction is some of the qualities of people with high emotional intelligence. Sportsmanship dimension of UCB has been described as the student's ability to face inconvenience and find ways to come out of it. Students with better emotional intelligence perceive difficulties early and analyse means to solve it. Utilizing emotion for solving problems, creative measures to motivate self and others are some of the components of emotional intelligence. Enthusiasm dimension of UCB as has been stated by U-Thaiwat et al.(2017) is students' urge to do something new by exploring opportunities. This is significant with emotional intelligence as it is ingrained in its description as utilization of emotion to find a creative solution for motivating self and others. Interpersonal relations remain healthy when a person displays a willingness to help others, try to improve the environment by remaining social, disciplined, talks good about the institution and sustain inconvenient situation without causing difficulty to others. Emotional Intelligence is significant to these dimensions and overall UCB. Sharma and Mahajan (2017) observed a significant relationship between Emotional Intelligence and Organizational Citizenship Behaviour of Bank employees of Jammu and Kashmir, India. They viewed emotional intelligence needs to be fostered in organizations to achieve a positive outcome like organizational citizenship behaviour (Sharma \& Mahajan, 2017). Miao et al(2017) viewed that Emotional Intelligence may help to motivate employees as it is related to empathy and in their meta-analysis opined that considerable literature has related El to Empathy. Widiani, Putri, Sari, and Wirajaya (2019) based on their study in Bali, Indonesia opined when an employee has high intelligence, he/she shows more love for the Company through organizational citizenship behaviour. This logic holds good particularly for the conscientiousness dimension of UCB as the students with high emotional intelligence display their love for the University by projecting its good image to the society and walking the extra mile for the benefit of the university.

Significant differences have been observed between Postgraduate and Undergraduate Management students regarding their ability to perceive emotion, managing self-emotion, managing others emotion, utilization of emotion and emotional intelligence, PG students have scored higher in these regards. Some research has demonstrated age serves as a factor in enhancing emotional intelligence (e.g., Cabello, Sorrel, Fernandez-Pinto, Extremera, \& Fernandez-Berrocal, 2016; Pooja \& Pranab, 2016), though in most of these studies comparison has 


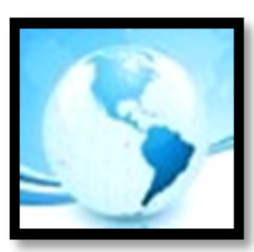

\section{MALAYSIAN ONLINE JOURNAL OF EDUCATIONAL MANAGEMENT (MOJEM)}

been drawn between adolescent, adult and aged population. Here the sample taken was within the age bracket of 21-24 with a mean age of PG Students at 23.6 and UG Students at 21.3, hence, age might not be having significant influence on their Emotional Intelligence, rather long stay in the university, exposed to management education, performing in teamwork develops within the students' capacity to perceive emotion, managing self, and others emotion and utilization of emotion in the environment. They have also been rated high regarding UCB and all its dimensions. Long stay within the environment brings with them adoption with the environment which otherwise might not be possible for a new entrant. Scoring high by the Postgraduate Students on the Undergraduate Students can also be ascribed to the social exchange theory. Years of study under the teachers, university meeting their needs and giving them identity as Post Graduate Management Student serves as a morale booster for them. Exposure to students of other universities, industries, and communities, studying in a multi-cultural environment might have developed a feeling of oneness with others, a sense of belongingness to the university, and a complying attitude with the regulations. Under-Graduate Students are just pass out from High School and new to the university environment.

Significant differences have been observed in the Perception of Emotion part of El between male and female participants. Turnipseed and Vandewaa (2012) explained that social expression is more acceptable to women than men. Females considering these characteristics may be in an advantageous position than men to perceive the emotion of others. Pooja and Pranab (2016) explained that women in India faced discrimination from their male colleagues and society in the previous decades and since then, the society is changing wherein women scored higher than men in their study. Fischer et al. (2018) added that as women undertake different social-emotional roles like child-care, family orientation as well as a duty to the organization they develop a better capability to perceive emotion. Memon et al. (2019) also found women have higher perceiving power of emotion than men.

Women have scored higher than male participants concerning their UCB. Sinha and Kumar (2004) described a form of achievement goal in India is social cause such as becoming good to others, extending help, obedience to seniors and authority, etc. Women being more involved in family affairs develop these achievement goals since childhood. It might be the reason as to why they have been rated high with the dimensions of UCB as most of them involve meeting these achievement goals.

\section{IMPLICATIONS}

Exploration of the relationship between Emotional Intelligence and University Citizenship Behaviour of the Management Students is an addition to the literature. Whereas many studies have established the relationship between OCB and emotional intelligence, the relationship between UCB and Emotional Intelligence is a new development.

This study showed a significant relationship between emotional intelligence and UCB and its different dimensions. This is identical to the results observed concerning the relationship between OCB and Emotional Intelligence in West, India, and Far-East (e.g., Vandewaa et al., 2016; Sharma \&Mahajan, 2017; Widiani et al., 2019).

Differences have been observed in Perception, Managing own and others emotion, utilization of emotion, and overall emotional intelligence of the Postgraduate and Undergraduate Management Students. A higher score of PG students over that of UG students regarding the different dimensions of UCB is a remarkable finding of the study. This also indicates that the curriculum of management education engaging students in several activities aiming at developing teamwork, raising their involvement and a sense of discipline is creating a desirable effect. Further exploration of this aspect may help the Universities to work in this direction with enhanced design in curriculum resulting in the development of emotional intelligence and different dimensions regarding UCB of management students. 


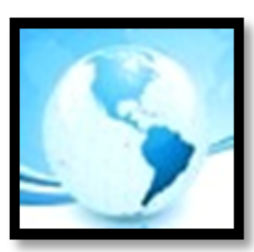

\section{MALAYSIAN ONLINE JOURNAL OF EDUCATIONAL MANAGEMENT (MOJEM)}

The identification of higher UCB of female students is an addition to the literature. In Universities, female students take an active part in different community development and cultural activities along with their male counterparts, though in many instances' university authorities may not take any special notice to it. This study may help university authorities to keep this aspect in mind so those female students can be encouraged further to take part in different extra-curricular activities.

Jain (2012) predicted that emotional intelligence may provide a competitive advantage to newly emerging organizations in the field of information technology and business process outsourcing. These organizations employ a large number of young educated people in India and also pay well. To create employable workforce Universities need to continuously focus on improving the emotional intelligence of its students and also their citizenship behaviour so that they become a responsible citizen of the future organization.

\section{CONCLUSION \& RECOMMENDATIONS}

This research has been conducted on management students of two Universities wherein management education is imparted in the state of Tripura to examine the relationship between their Emotional Intelligence and University Citizenship Behaviour and its different dimensions. To analyse the relationship Pearson's Correlation and Regression method was used; Emotional Intelligence is significantly related to University Citizenship Behaviour and its different dimension.

To explore the differences in emotional intelligence, its components, and UCB, its dimensions between Undergraduate and Postgraduate Students Independent Sample T-Test and ANOVA was used. Canonical Correlation was undertaken which was in agreement with the findings. It has been found that Emotional Intelligence, its components, UCB, and all its dimensions were higher among Postgraduate Students.

To investigate differences between male and female students the same method as was for Postgraduate and Undergraduate Students followed. It has been found that female students scored higher in the Perception of Emotion component. Female participants also ranked higher in UCB and all of its dimensions

From the study's results, it has been observed that this study can be extended further for the betterment of management education and needs to be undertaken in some Universities located in different parts of India so that a representative sample of the management students in India can be analysed. Higher scores of PG Students concerning emotional intelligence and UCB can be attributed to the curriculum devised for its improvement as the difference in age of Postgraduate and Undergraduate Students is not wide. To have a conclusive view on this aspect, the experiment of Nelis et al. (2009) can be adopted and this study needs to be further continued for a certain period so that one can safely assume that the curriculum is helping to contribute to increasing emotional intelligence of the students. Such a study can establish this fact and a standard curriculum among different universities of the country can be designed.

This study can also be undertaken among different disciplines of the University as high emotional intelligence and citizenship behaviour is required not only for managerial employment but also for many other categories.

\section{ACKNOWLEDGEMENT}

Author acknowledges the support extended by Sangita Ghosh and Rajdip Mazumdar, MBA Students of ICFAI University Tripura in data collection for this study. 


\section{REFERENCES}

Ahmad, K.Z.(2011). The association between training and organizational citizenship Behavior in the digital world, Communications of IBIMA,1-11. doi: 10.5171/2011.448699

Antony, J. M. (2013). The influence of emotional intelligence on organizational commitment and organizational citizenship behavior, International Journal of Social Science \& Interdisciplinary Research, 2(3),110-115

Ariani, D.W.(2013). The relationship between employee engagement, organizational citizenship behavior, and counterproductive work behavior, International Journal of Business Administration, 4(2), 46-56

Bar-On, R. (1997). Emotional Intelligence Quotient Inventory: A Measure of Emotional Intelligence. Toronto, ON: Multi Health Systems, Inc.

Basu, E., Pradhan, R.K.\& Tewari, H.R. (2017).Impact of organizational citizenship behavior on job performance in Indian healthcare industries: The mediating role of social capital. International Journal of Productivity and Performance Management, 66(6), 780-796. https://doi.org/10.1108/IJPPM-02-2016-0048

Beck, M., \& Libert, B. (2017) The rise of Al makes emotional intelligence more important. Harvard Business Review. Retrieved fromhttps://hbr.org/2017/02/the-rise-of-ai-makes-emotional-intelligence-more-important

Cabello, R., Sorrel, M.A., Fernandez-Pinto, I., Extremera, N., \& Fernandez-Berrocal, P. (2016) Age and gender differences in ability emotional intelligence in adults: A cross sectional study. Developmental Psychology,52(9), 1486-1492.https://doi.org/10.1037/dev0000191.

Candigarh, L.,\& Vasisht, A.(2017). Impact of emotional intelligence on organization citizenship behaviour: A study among nurses of government and private hospitals in and around Chandigarh. Amity Journal of Training and Development, 2(1), 1-18.

Cazen, A. M., \& Nastasa, L.E.(2014).Emotional intelligence, satisfaction with life and burnout among university students. Procedia - Social and Behavioral Sciences, 180, 1574- 1578.

Chehrazi, S.,\& Shakib, M. (2014).A study on the relationship between emotional intelligence, organizational commitment and organizational citizenship behavior, Management Science Letters, 4(6), 1103-1106.

Chin, S. T. S., Anantharaman, R. N.\& Tong, D. Y. K. (2011). Emotional intelligence and organizational citizenship behaviour of manufacturing sector employees: An analysis. Management, 6(2), 32-49.

Ciarrochi, J., Chan, A.Y.C., \& Bajgar, J.(2001).Measuring emotional intelligence in adolescents, Personality and Individual Differences, 31(7), 1105-1119.

Costa, A., \& Faria, L.(2015). The impact of emotional intelligence on academic achievement: A longitudinal study in Portuguese secondary school. Learning and Individual Differences, 37(1), 38-47. doi: 10.1016/j.lindif.2014.11.011

Dargahi, H.,\& Morshedi, T. M. (2017). The relationship of organizational citizenship behavior with job satisfaction and organizational commitment of nurses among Public Hospitals of Tehran University of Medical Sciences. Manage Strat Health Syst, 2(3),234-246. http://mshsj.ssu.ac.ir/article-1-105-en.html

Ehtiyar, V.R., Alan, A.A., \&Omiiris, E. (2010).The role of organizational citizenship behavior on university student's academic success, Tourism and Hospitality Management, 16(1),47-61.

Farrell, S.K.\& Finkelstein, L.M. (2007). Organizational citizenship behaviour and gender: Expectations and attributions for performance. North American Journal of Psychology, 9(1),81-96.

Fischer, A.H., Kret, M.E., \& Broekens, J. (2018).Gender differences in emotion perception and self-reported emotional intelligence: A test of the emotion sensitivity hypothesis. PLOS ONE, 13(1), 1-19. https://doi.org/10.1371/journal. pone.01907

Goleman, D.(1995). Emotional Intelligence, New York: Bantam Books.

Harms, P.D., \& Crede, M.(2010). Emotional intelligence and transformational and transactional leadership: A metaanalysis. Journal of Leadership \& Organizational Studies, $17(1) \quad 5$ 17.https://doi.org/10.1177/1548051809350894

Hodzic, S., Scharfen, J., Ripoll, P., Holling, H., \& Zenashi, F. (2017).How efficient are Emotional Intelligence trainings: A meta-analysis. Emotion Review, 10(2), 138-148.https://doi.org/10.1177/1754073917708613

Hoffman, B.J., Blair, C.A., Meriac, J.P., Woehr, D.J. (2007). Expanding the Criterion Domain? A Quantitative Review of the OCB Literature, Journal of Applied Psychology, 92(2), 555-566, doi 10.1037/0021-9010.92.2.555 


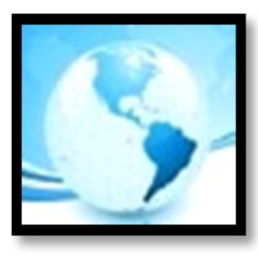

Ismail, S., Iqbal, Z., \& Adeel, M.(2018). Impact of organizational justice and organizational citizenship behavior on employees' performance.International Journal of Human Resource Studies, 8(2), 187-200 doi:10.5296/ijhrs.v8i2.13070

Jain, A. K. (2009). Exploring the relative relevance of organizational citizenship behaviour and emotional intelligence. Journal of the Indian Academy of Applied Psychology, 35(1),87-97.

Jain, A.K.(2012). Does emotional intelligence predict impression management? Journal of Organizational Culture, Communications and Conflict, 16(2), 11-24.

Joseph, D. L., \& Newman, D. A. (2010). Emotional intelligence: An integrative meta-analysis and cascading model. Journal of Applied Psychology, 95(1)54-78. https://doi.org/10.1037/a0017286

Lambert, E.G. (2010). The relationship of organizational citizenship behavior with job satisfaction, turnover intent, life satisfaction, and burnout among correctional staff, Criminal Justice Studies, 23(4),361380. doi: 10.1080/1478601X.2010.516533

Le Pine, J.A., Erez, A., \& Johnson, D.E.(2002). The Nature and Dimensionality of Organizational Citizenship Behavior: A Critical Review and Meta-Analysis, Journal of Applied Psychology, 87(1), 52-65, doi 10.1037//00219010.87.1.52

Lovell, S.E., Kahn, S.A., Anton, J., Davidson, A., Dowling, E., Post, D.\& Mason, C. (1999). Does gender affect the link between organizational citizenship behavior and performance evaluation? Sex Roles, 41(5-6),469-478.

MacCann, C., Fogarty, G., Zeidner, M., \& Roberts, R. (2011). Coping mediates the relationship between emotional intelligence (EI) and academic achievement. Contemporary Educational Psychology, 36(1),60-70.

Mattingly, V., \& Kraiger, K. (2018).Can emotional intelligence be trained? A meta-analytical investigation.Human Resource Management Review, 29(2), 140-155 https://doi.org/10.1016/j.hrmr.2018.03.002

Mayer, J.D., \& Salovey, P.(1997). What is Emotional Intelligence? In P. Salovey \&D. Sluyter (Eds.), Emotional Development and Emotional Intelligence: Implications for Educators (pp. 3-31). New York: Basic Books.

Memon, S.A., Dhamyal, H., Wright, O., Justice, D., Palat, V., Boler, W., Wen, Y., Raj, B., \& Singh, R. (2019). Detecting gender differences in perception of emotion in crowd sourced data. ArXiv, abs/1910.11386.

Miao, C., Humphrey, R. H., \& Qian, S. (2017). Are the emotionally intelligent good citizens or counterproductive? A meta-analysis of emotional intelligence and its relationships with organizational citizenship behaviour and counterproductive work behaviour, Personality and Individual Differences, 16,144156.http://dx.doi.org/10.1016/j.paid.2017.04.015

Michael J, Clarke, Anthony, D.G. Marks, \& Amy D. Lykins (2015). Bridging the gap: the effect of gender normativity on differences in empathy and emotional intelligence. Journal of Gender Studies, 25(5), 522539. doi: 10.1080/09589236.2015.1049246

Mishra, P.S., \& Mahapatra, A.K.D.(2010). Relevance of emotional intelligence for effective job performance: An empirical study. Vikalpa, 35(1),53-61

Naghdi, M., \& Shatalebi, B.(2013). Emotional intelligence and the organizational citizenship behavior in the employees of Esfahan Municipality, International Journal of Marketing \& Technology, 3(2), 1-14

Nasurdin, A.M., Ahmad, N.H., \& Tan, C.L.(2014). Cultivating service-oriented citizenship behavior among hotel employees: The instrumental roles of training and compensation, Serv. Bus,9, 343-360. doi:10.1007/s11628-014-0230-5

Nelis, D., Quoidbach, J., Mikolajczak, M., \& Hansenne, M. (2009) Increasing emotional intelligence: (How) is it possible? Personality and Individual Differences, 47, 36-41; doi:10.1016/j.paid.2009.01.046

Ng,T.W.H., Lam, S.S.K.,\& Feldman, D.C.(2016). Organizational citizenship behavior and counter productive work behavior: Do males and females differ? Journal of Vocational Behavior, 93, 1132.https://doi.org/10.1016/j.jvb.2015.12.005

O’ Boyle, E.H., Humphrey, R.H., Pollack, J. M., Hawver, T.H., \& Story, P.A.(2011). The relation between emotional intelligence and job performance: A meta-analysis. Journal of Organizational Behaviour, 32(5), 788818. https://doi.org/10.1002/job.714 


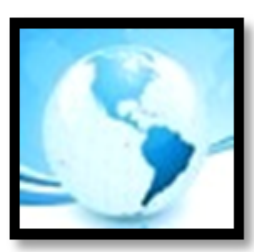

MALAYSIAN ONLINE JOURNAL OF

EDUCATIONAL MANAGEMENT

(MOJEM)

Pekaar, K. A., Bakker, A. B., Born, M. P\& van der Linden, D. (2018). The consequences of self- and other-focused emotional intelligence: Not all sunshine and roses. Journal of Occupational Health Psychology,24(4), 450466.http://dx.doi.org/10.1037/ocp0000134

Petrides, K. V., Hudry, K., Michalaria, G., Swami, V., \& Sevdalis, N. (2011) .A comparison of the trait emotional intelligence profiles of individuals with and without Asperger syndrome Autism, 15, 671-682.

Pooja, P., \& Pranab, K.(2016). Demographic variables and its effect on emotional intelligence: A study on Indian service sector employees. Ann Neurosci,23,18-24.doi: 10.1159/000443552

Popescu, A.M., \& Desconu, A. (2013).High school, organization citizenship behavior moderator, Journal of Social and Behavioral Science, 92,735-740

Salovey, P., \& Mayer, J.D. (1990).Emotional intelligence, Imagination, Cognition and Personality, 9(3), 185211.https://doi.org/10.2190/DUGG-P24E-52WK-6CDG

Schlegel, K., Mehu, M., van Peer, J.M., \&Scherer, K.R.(2017). Sense and sensibility: The role of cognitive and emotional intelligence in negotiation. Journal of Research in Personality,74, 6-15.https://doi.org/ 10.1016/j.jrp.2017.12.003

Schlaerth, A., Ensari, N., \& Christian, J.(2013). A meta-analytical review of the relationship between emotional intelligence and leaders' constructive conflict management, Group Processes \& Intergroup Relations, 16(1), 126-136, doi:10.1177/1368430212439907

Schutte, N.S., Malouff, J.M., Hall, L.E., Haggerty, D.J., Cooper, J.T., Golden, C.J., \& Dornheim, L. (1998).Development and validation of a measure of emotional intelligence. Personality and Individual Differences, 25,167-177

Schutte, N.S., Malouff, J.M., Bobik, C., Coston, T.D., Greeson, C., Jedlicka, C., Rhodes, E., \& Wendrof, G. (2001) . Emotional intelligence and interpersonal relations,Journal of Social Psychology, 141(4), 523-536.

Schutte, N. S., Malouff, J. M., \& Bhullar, N. (2009). The assessing emotions scale. In C. Stough, D. H. Saklofske \& J. D. A. Parker (Eds.), The Springer series on human exceptionality. Assessing emotional intelligence: Theory, research, and applications (pp. 119-134). US: Springer Science + Business Media.

Sharma, K., \& Mahajan, P. (2017). Relationship between emotional intelligence and organisational citizenship behaviour among bank employees.Pacific Business Review International, 9(11),20-29.

Sinha, J.B.P., \&Kumar, R. (2004).Methodology for understanding Indian culture.The Copenhagen Journal of Asian Studies, 19, 89-104

Tofighi, M., Tirgari, B., Fooladvandi, M., Rasouli, F., \& Jalali, M. (2015) Relationship between emotional intelligence and organizational citizenship behaviour in critical and emergency nurses in south east of Iran. Ethiopian Journal of Health Sciences, 25(1), 79-88.

Turnipseed, D.L., \& Vandewaa, E.A. (2012).Relationship between emotional intelligence and organizational citizenship behavior.Psychological Report, 110(3), 899-914 doi:10.2466/01.09.20.21.PR0.110.3.899-914

Ueda, Y.,\& Yoshimura,A.(2010). University citizenship behavior in class: The effect of professor's lecture justice on students' diligence. Review of Asian and Pacific Studies, 36, 87-99.

U-Thaiwat, P., Supparerkchaisakul, N., Mohan, K.P., \& Fansler, K. (2017). Developing a scale for university citizenship behavior: Thai and U.S. Academic Contexts. International Journal of Behavioral Science, 12(2), 71-89.

Uyanik, G.K., \& Guler, N.(2013). A study on multiple linear regression analysis, Procedia- Social and Behavioral Sciences, 106, 234-240.doi: 10.1016/j.sbspro.2013.12.027

Vandewaa, E.A.,\& Turnipseed, D.L.(2012). Emotional intelligence and organizational citizenship behavior of University Professors, International Journal of Interdisciplinary Social Sciences, 6(7),1-12. doi:10.18848/1833-1882/CGP/v06i07/52115

Vandewaa, E.A., Turnipseed, D.L., \&Cain, G.(2016). Panacea or Placebo? An evaluation of the value of emotional intelligence in healthcare workers, Journal of Health and Human Services Administration, 36(4), 438-477 https://www.jstor.org/stable/43948684

Wanxian, L., \& Weiwu, W. (2007).A demographic study on citizenship behavior as in-role-orientation. Personality and Individual Differences, 42(2), 225-234 


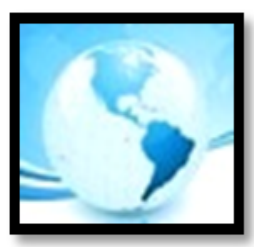

MALAYSIAN ONLINE JOURNAL OF

EDUCATIONAL MANAGEMENT

(MOJEM)

Wojciechowski, J., Stolarski, M \& Matthews, G. (2014).Emotional intelligence and mismatching expressive and verbal messages: A contribution to detection of deception. PLoS ONE9(3), 1-13. doi:10.1371/journal.pone.0092570

Widiani, N.P., Putri, I.G.A.M.A.D., Sari, M.M.R., \& Wirajaya, I.G.A.(2019). The effect of love of money and emotional intelligence on employee performance with organizational citizenship behavior as mediating variable, International Research Journal of Engineering, IT \& Scientific Research, 5(1), 3949. https://doi.org/10.21744/irjeis.v5n1.596

Yaghoubi, E., Mashinchi, S. A.,\& Hadi, A. (2011).An analysis of correlation between organizational citizenship behavior (OCB) and emotional intelligence (EI), Modern Applied Science, 5(2), 119-123.

Yunus, N. H. (2012). Displaying employees' organizational citizenship behaviour: The impact of emotional intelligence and leader-member exchange in development bank in Malaysia, International Journal of Social Science and Humanity, 2(4), 320-344 